\title{
Hypocomplementemia in Reye Syndrome: Relationship to Disease Stage, Circulating Immune Complexes, and C3b Amplification Loop Protein Synthesis
}

\author{
HAROLD K. MARDER, ${ }^{(2) !}$ C. FREDERIC STRIFE, JUDITH FORRISTAL, JACQUELINE PARTIN, \\ AND JOHN PARTIN \\ The Children's Hospital Research Foundation and the Department of Pediatrics, University of Cincinnati College of \\ Medicine, Cincinnati, Ohio, USA
}

Summary

Measurement of C1q, C2, C4, C5, C6, factor B, properdin, $\beta 1 \mathrm{H}$, and C3bINA were made in acute sera from 31 patients with Reye syndrome. Abnormalities were found in 18 patients. The magnitude of the complement component depression correlated with disease severity. Sera from patients with stage IV illness had significantly lower complement levels than did sera from patients with stage I $(P<0.001)$, II $(P<0.05)$, and III $(P<0.05)$ disease. Circulating immune complex measurements were performed on all 31 acute sera and were present in six (19\%). However, from the results of the present study, it would appear that in the majority of the patients circulating immune complexes are not the cause of the lowered levels of, at least, C3 and factor B. Rather, these low levels could be explained as secondary to reductions in the levels of the C3b amplification loop control proteins $\beta 1 \mathrm{H}$ and C3bINA.

\section{Speculation}

In Reye syndrome, the exact mechanism responsible for reduction of many complement proteins including $\beta 1 \mathrm{H}$ and $\mathrm{C} 3 \mathrm{bINA}$ remains obscure. Although circulating immune complexes are present transiently, the observed low levels of at least C3 and factor $B$ are best explained by hyposynthesis of their control proteins, $\beta 1 \mathrm{H}$ and C3bINA. Although the mechanism of this hyposynthesis is unknown, the absence of a pattern of complement depression typical of severe liver disease suggests a generalized cellular disturbance resulting in impaired complement protein synthesis.

Reye syndrome is a systemic illness of unknown pathogenesis manifested by acute encephalopathy and invariably associated with a characteristic panlobular microvesicular fatty liver (11). Typically, children present with vomiting and progressive encephalopathy occurring within $1 \mathrm{wk}$ after onset of certain viral illnesses, most notably influenza A or B and varicella. Recently, abnormalities of classical complement pathway components have been described by Pickering et al. (12). Immune complex depletion of early complement components was suggested as a potential explanation for the observed low levels of Clq, C4, and C2 in three of their 16 patients. The present report, although confirming these previous observations (12), notes a direct association between the severity of the complement abnormalities and the disease stage. Circulating immune complexes were found in sera from some patients but in most factors other than immune complexes appear to be responsible for the low serum complement levels.

\section{PATIENTS AND METHODS}

Acute serum was obtained on admission from 31 patients who met previously established diagnostic criteria of Reye syndrome $(11,13)$. Clinical staging upon admission was assessed by the method of Lovejoy et al. (9). Seven of 31 patients were in stage I, four in stage II, 14 in stage III, and six in stage IV. Three patients, all with stage IV disease, ultimately died. The illness in 12 patients was preceded by varicella infection, whereas the remainder experienced an influenzal prodrome. Patients were treated with supportive therapy and exchange transfusion where indicated (1). All acute sera were collected before such manipulations and stored at $-70^{\circ} \mathrm{C}$ until used. Convalescent sera were obtained from 18 of 28 survivors (five with stage I, four with stage II, and nine with stage III disease). Sera from five patients who had varicella encephalitis without evidence of Reye syndrome also were evaluated. All sera obtained from patients and reported in the present study was done so with parental approval and approval from the Human Research Committee at the Children's Hospital Medical Center.

Measurements of $\mathrm{Clq}, \mathrm{C} 4, \mathrm{C} 3, \mathrm{C} 5, \beta 1 \mathrm{H}, \mathrm{C} 3 \mathrm{~b}$ inactivator (C3bINA), factor B, and properdin were made by radial immunodiffusion as previously described $(4,15,20)$. C2 was measured by radial immunodiffusion using antibody prepared in goats by injection of purified C2 (Cordis Laboratories, Miami, FL) and rendered monospecific by absorption with heated normal human serum. Specificity was confirmed by finding an arc of identity by double diffusion in agarose with anti-C2 kindly provided by Dr. Enrique Vallota. Radial immunodiffusion measurement of C6 used antibody raised in goats by injection of purified $\mathrm{C} 6$ obtained from Dr. Carlos Arroyave and rendered monospecific by absorption with normal human serum. The precipitin arc formed by this antiserum had a reaction of identity with anti-C6 kindly provided by Dr. Arroyave. Measurements of $\mathrm{Clq}, \mathrm{C} 2$, properdin, C3bINA, and $\mathrm{C} 6$ were standardized using a reference serum quantitated by the Department of Molecular Immunology of the Scripps Clinic and Research Foundation. The normal range (mean \pm 2 S.D.) for all complement components was determined from measurements of levels in sera from 135 healthy adult hospital personnel.

Circulating immune complexes were sought using a modification of the solid phase Clq method of Hay et al. (5). The method was modified by substituting ethylenediamine-tetraacetate for $56^{\circ} \mathrm{C}$ heating of the sera and Tween 20 (MCB, Norwood, $\mathrm{OH}$ ) for gelatin (18). Levels $<7 \mu \mathrm{g}$ aggregated IgG equivalents per $\mathrm{ml}$ are considered to be elevated as determined by measurements of immune complexes in 20 healthy children. C3 nephritic factor was measured as previously described (17). Statistical analyses were performed using the Student $t$ test, Snedecor's $F$ test, and linear regression analysis by the method of least squares. 


\section{RESULTS}

As shown in Figure 1, measurements of $\mathrm{Clq}, \mathrm{C} 2, \mathrm{C} 4, \mathrm{C} 3, \mathrm{C} 5$, $\mathrm{C} 6$, factor $\mathrm{B}$, properdin, $\beta 1 \mathrm{H}$, and C3bINA were made in acute sera from all 31 patients. In eleven of 31 acute sera, levels of three or more complement proteins were depressed, in three sera two were depressed, and in four a single protein was depressed.

The relationship between the complement protein levels and the clinical stage of disease is shown in Table 1 . The seven patients with stage I disease had complement protein levels which did not significantly deviate from normal; one had isolated reduction of Clq. Two of the four patients with stage II disease had entirely normal serum complement profiles whereas the remaining two patients had depression of two and four serum complement proteins. Levels of $\mathrm{Clq}$ and $\mathrm{C} 3$ were significantly low when compared to normals. Seven of 14 sera from patients with stage III disease had at least two serum complement proteins depressed, and levels of $\mathrm{C} 2, \mathrm{C} 3, \mathrm{C} 5, \mathrm{C} 6$, and $\beta 1 \mathrm{H}$ were significantly depressed when compared to normals. Five of six sera from patients with stage IV disease had two or more complement proteins depressed, and all complement proteins except properdin were significantly low when compared to normals. As seen in Table 2, sera from patients with stage IV illness had significantly lower complement levels than did sera from patients with stage I $(P<0.001)$, II $(P<0.05)$, and III $(P<0.05)$ disease. In addition, regression analysis indicated a significant relationship between the clinical stage of illness and the number of low complement proteins $(n=31 ; r=0.62 ; P$ $<0.001$ ).
Convalescent sera from 18 patients were available for complement protein determinations. In four specimens, a single protein concentration was low. One of these four patients was found to have heterozygous $\mathrm{C} 2$ deficiency as determined by family studies.

Complement protein levels were normal in five patients with varicella encephalitis with no evidence of Reye syndrome.

Circulating immune complex measurements were performed on all 31 acute sera. Six (19\%) contained circulating immune complexes; four from patients with stage III disease $(29 \%)$ and two from patients with stage IV disease (33\%). The stage III patients had levels of $8.6,10,12$, and $27.5 \mu$ g aggregated IgG equivalents per $\mathrm{ml}$, whereas stage IV patients had levels of 42.5 and $127 \mu \mathrm{g}$ aggregated $\mathrm{IgG}$ equivalents per $\mathrm{ml}$. Four of the six patients with immune complexes had marked disturbances in their complement profiles with at least four components depressed. The remaining two patients, whose immune complex levels were the lowest $(8.6$ and $10 \mu \mathrm{g}$ aggregated $\mathrm{IgG}$ equivalents per $\mathrm{ml}$ ), had only one component depressed. One of these two patients had heterozygous C2 deficiency. Convalescent sera were available from four of six patients who initially were found to have circulating immune complexes. No complexes were present in the convalescent sera.

To provide insight into the cause of hypocomplementemia and its relationship to the circulating immune complexes, the data were judged according to the correlation between control and component proteins of the $\mathrm{C} 3 \mathrm{~b}$ amplification loop as described by Wyatt et al. (19). There is normally a linear relationship between the sum of the concentrations of $\mathrm{C} 3$ and factor $\mathrm{B}$, on the one hand,

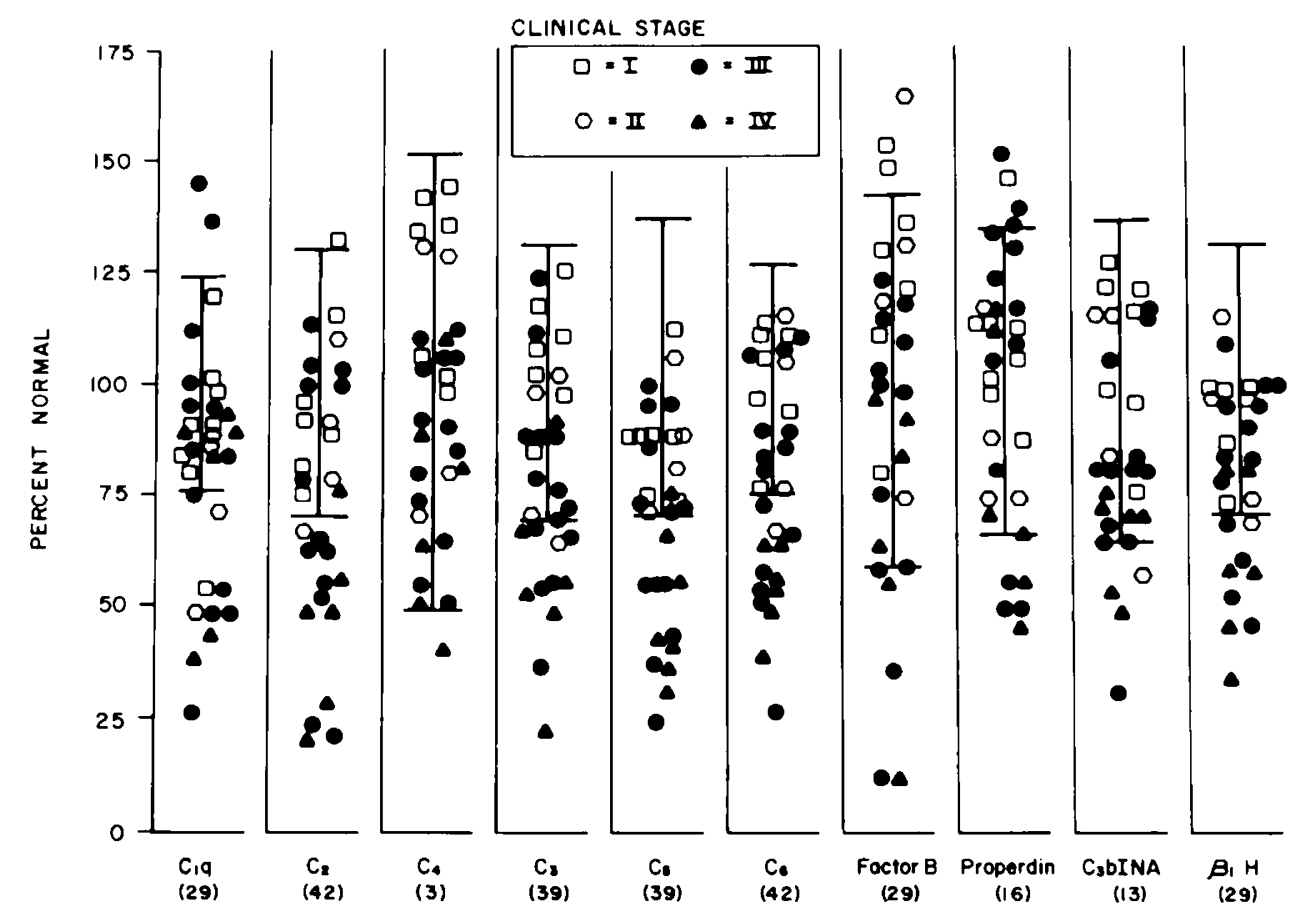

Fig. 1. Acute serum complement protein levels from 31 patients with Reye syndrome. Horizontal hars, normal ranges (mean \pm 2 S.D.). Numbers in parentheses, percentage of sera with abnormally low component levels.

Table 1. The significance of the difference between serum complement levels in patients with varying stages of Reye syndrome and in 135 normal subjects

\begin{tabular}{|c|c|c|c|c|c|c|c|c|c|c|}
\hline \multirow{2}{*}{$\begin{array}{c}\text { Clinical } \\
\text { stage }\end{array}$} & \multicolumn{10}{|c|}{$P$} \\
\hline & $\mathrm{Clq}$ & $\mathrm{C} 2$ & $\mathrm{C} 4$ & $\mathrm{C} 3$ & $\mathrm{C} 5$ & $\mathrm{C} 6$ & Factor B & Properdin & C3bINA & $\beta 1 \mathrm{H}$ \\
\hline I & N.S.' & N.S. & N.S. & N.S. & N.S. & N.S. & N.S. & N.S. & N.S. & N.S. \\
\hline II & $<0.01$ & N.S. & N.S. & $<0.05$ & N.S. & N.S. & N.S. & N.S. & N.S. & N.S. \\
\hline III & N.S. & $<0.001$ & N.S. & $<0.001$ & $<0.001$ & $<0.001$ & N.S. & N.S. & N.S. & $<0.05$ \\
\hline IV & $<0.01$ & $<0.001$ & $<0.01$ & $<0.001$ & $<0.001$ & $<0.001$ & $<0.01$ & N.S. & $<0.001$ & $<0.001$ \\
\hline
\end{tabular}

'N.S., no significant difference. 
Table 2. Comparison of serum complement levels of stage IV patients with those of patients with Stage I, II, and III illness

\begin{tabular}{|c|c|c|c|c|c|c|c|c|c|c|}
\hline \multirow{2}{*}{$\begin{array}{l}\text { Clinical } \\
\text { stage }\end{array}$} & \multicolumn{10}{|c|}{$P$} \\
\hline & $\mathrm{Clq}$ & $\mathrm{C} 2$ & $\mathrm{C} 4$ & $\mathrm{C} 3$ & C5 & $\mathrm{C} 6$ & Factor B & Properdin & C3bINA & $\beta 1 \mathrm{H}$ \\
\hline I vs. IV & N.S. ${ }^{1}$ & $<0.001$ & $<0.001$ & $<0.001$ & $<0.001$ & $<0.001$ & $<0.001$ & $<0.001$ & $<0.001$ & $<0.001$ \\
\hline II $v s$. IV & N.S. & $<0.05$ & $<0.05$ & $<0.05$ & $<0.001$ & $<0.01$ & $<0.01$ & N.S. & N.S. & $<0.05$ \\
\hline III $v s$. IV & N.S. & $<0.05$ & N.S. & N.S. & $<0.05$ & $<0.05$ & N.S. & $<0.05$ & N.S. & N.S. \\
\hline
\end{tabular}

${ }^{1}$ N.S., not significant.

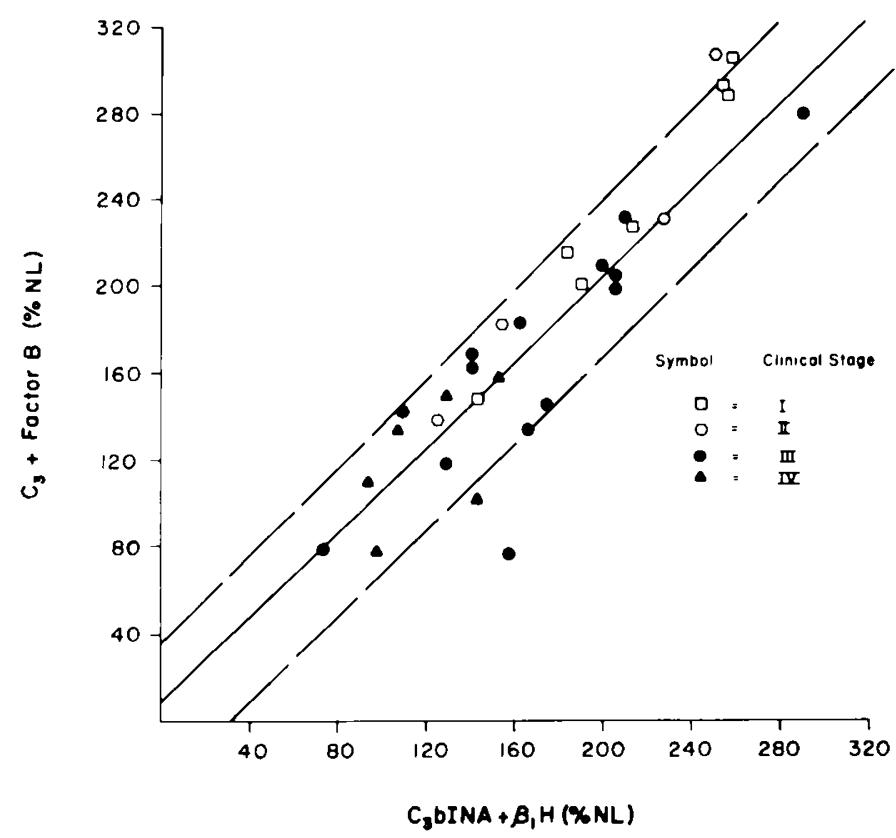

Fig. 2. The sum of the $\mathrm{C} 3 \mathrm{~b}$ amplification loop control protein levels $(\beta 1 \mathrm{H}+\mathrm{C} 3 \mathrm{bINA})$ is plotted against the sum of the component protein levels $(C 3+$ factor $B)$ measured in acute serum specimens from patients with Reye syndrome. All values are expressed as a percentage of the normal adult levels. The normal regression $(-)$ and $95 \%$ error of the prediction (-- $)$ were determined as previously reported (19).

and of $\beta 1 \mathrm{H}$ and C3bINA on the other, when the concentrations are expressed as percent of the normal adult level. The limits of this relationship in normal subjects are shown in Figure 2. With serum specimens from normal adults, the correlation coefficient for this relationship is 0.83 , and for adults, infants, and cord serum combined, $r=0.91$. The presence of circulating complement reactive material alters this relationship by lowering $\mathrm{C} 3+$ factor $B$ below the level expected from the concurrent $\beta 1 \mathrm{H}$ and C3bINA levels. As can be seen in Figure 2, in serum from 29 patients with Reye syndrome, the levels of $\mathrm{C} 3$ and factor $\mathrm{B}$ were in the range expected for the $\beta 1 \mathrm{H}$ and C3bINA levels. In two sera, the sum of $\mathrm{C} 3$ and factor $\mathrm{B}$ was disproportionately lower than expected for the sum of $\beta 1 \mathrm{H}$ and $\mathrm{C} 3 \mathrm{bINA}$. The hypocomplementemia in these two specimens is thus eligible to be due to circulating complement reactive material. Both sera contained circulating immune complexes. One was from the stage III patient with $27.5 \mu \mathrm{g}$ of aggregated IgG equivalent per $\mathrm{ml}$, and the other was from the stage IV patient with $127 \mu \mathrm{g}$ of aggregated $\mathrm{IgG}$ equivalent $/ \mathrm{ml}$.

C 3 nephritic factor was absent in all 31 acute sera.

\section{DISCUSSION}

This report confirms the previous observations of Pickering $e$ al. (12) demonstrating hypocomplementemia in patients with Reye syndrome. We have extended their observations by showing a relationship between the hypocomplementemia and the severity of the disease. Our results differ in that we observed a greater incidence of depression of the early complement components, $\mathrm{Clq}$ and $\mathrm{C} 2$, suggesting the possibility of classical pathway activation. Pickering et al. (12), noting low functional and/or protein levels of $\mathrm{Clq}, \mathrm{C} 4$, and $\mathrm{C} 2$ in three of their 16 patients, suggested that the complement abnormalities might be the result of depletion by immune complexes. In the present study, circulating immune complexes containing IgG and having the potential of initiating classical pathway activation were present in relatively low concentration in sera from four patients with marked abnormalities in complement component levels and in sera from two additional patients with mild complement component abnormalities.

From the results of the present study, it would, however, appear that in the majority of the patients, circulating immune complexes are not the cause of the lowered levels of, at least, C3 and factor B. This conclusion is based on the observation by Wyatt et al. (19) that the serum levels of $\mathrm{C} 3$ and factor $\mathrm{B}$ are, under normal conditions, largely controlled by the levels of the control proteins of the $\mathrm{C} 3 \mathrm{~b}$ amplification loop, $\beta 1 \mathrm{H}$ and C3bINA (Fig. 2). This relationship between the control proteins and $\mathrm{C} 3$ and factor $\mathrm{B}$ is consistent with in vitro observations of an absolute requirement for $\beta 1 \mathrm{H}$ in the cleavage of fluid phase C3b by C3bINA (3). The relationship between these proteins is preserved in serum from infants and cord blood and from patients with various chronic illnesses including nephrosis and malnutrition, even though $\mathrm{C} 3$ and factor B levels, by normal adult standards, may be significantly abnormal in these conditions. However, with complement reactive material present in the circulation, as occurs in hypocomplementemic glomerulonephritis, or in subjects in whom hyposynthesis is confined to $\mathrm{C} 3$ as in heterozygous $\mathrm{C} 3$ deficiency, the $\beta 1 \mathrm{H}-\mathrm{C} 3 \mathrm{bINA}$ control is lost, and the sum of $\mathrm{C} 3$ and factor $\mathrm{B}$ falls below the normal range. Applying this observation to the present data, the low C 3 and factor B levels in two specimens could have been the result of circulating complement reactive material because the sum of the levels of these two proteins fell below the normal range. In both specimens, immune complexes eligible to activate the classical pathway were present. In the remaining specimens, however, the low $\mathrm{C} 3$ and factor B levels could be said to be "physiologic," i.e., secondary to a reduction in $\beta 1 \mathrm{H}$ and C3bINA even though in some of these specimens immune complexes could be demonstrated.

Other mechanisms for hypocomplementemia were investigated. Adenovirus, influenza and varicella infections have been associated with hypocomplementemic glomerulonephritis $(7,14)$. Sera from five patients with varicella encephalitis had complement protein determinations to assess the contribution of a varicella prodrome to the hypocomplementemia. The complement component levels in these patients tended to be greater than 2 standard deviations above the mean, suggesting enhanced synthesis as the result of an acute phase reaction.

It may be hypothesized that the observed complement component abnormalities are a function of decreased hepatic synthesis resulting from the characteristic panlobular microvesicular fatty liver found in patients with severe Reye syndrome. Although many complement components are synthesized in the liver and are thus eligible for hyposynthesis in Reye syndrome, the specific pattern of reduction is not that expected with decreased hepatic synthesis alone. C4 levels, frequently depressed in both acute and chronic liver diseases $(2,10,16)$, were normal in 30 of 31 patients in the present study and in 8 of 10 patients studied by Pickering 
et al. (12). Levels of $\mathrm{C} 5$ and $\mathrm{Clq}$, both in normal concentration in acute and chronic liver disease $(2,16)$, were frequently reduced in acute sera from patients with Reye syndrome. There were, on the other hand, parallels between Reye syndrome and liver disease; in both $\mathrm{C} 3$ and $\mathrm{C} 6$ levels are reduced. Human complement component proteins are also synthesized in tissue monocytes, intestinal epithelial cells, and the spleen $(6,8)$. Thus, a more generalized hyposynthesis of complement proteins is likely responsible for the low levels observed in Reye syndrome.

In summary, hypocomplementemia is frequently found in patients with Reye syndrome and tends to reflect the severity of the underlying disease. The pattern of hypocomplementemia seen in many patients suggests classical pathway activation. This could be the result of the transiently circulating immune complexes demonstrable in some patients, but in most cases, the low levels of at least $\mathrm{C} 3$ and factor $\mathrm{B}$ are explained as secondary to reductions in the levels of the control proteins, $\beta 1 \mathrm{H}$ and C3bINA.

\section{REFERENCES AND NOTES}

1. Bobo, R. C., Schubert, W. K., Partin, J. C., and Partin, J. S.: Reye syndrome: treatment by exchange transfusion with special reference to the 1974 epidemic in Cincinnati, Ohio. J. Pediatr., 87: 881 (1975).

2. Charlesworth, J. A., Lawrence, S., Wordsall, R. A., Roy, L. P., and Broughton C. R.: Acute hepatitis: significance of changes in complement components Clin. Exp. Immunol., 28: 496 (1977).

3. Conrad, D. H., Carlo, J. R., and Ruddy, S.: Interactions of $\beta 1 \mathrm{H}$ globulin with cell bound C3b. J. Exp. Med.. 147: 1792 (1978).

4. Forristal, J., Iitaka, K., Vallota, E. H., and West, C. D.: Correlations between serum factor $\mathrm{B}$ and $\mathrm{C} 3 \mathrm{~b}$ inactivator levels in normal subjects and in patients with infections, nephrosis, and hypocomplementemic glomerulonephritis. Clin. Exp. Immunol., 28: 61 (1977).

5. Hay, S. C., Ninebaur, L. J., and Roitt, I. M.: Routine assay for the detection of immune complexes of known immunoglobulin class using solid phase Clq. Clin. Exp. Immunol., 24: 396 (1976)

6. Kohler, P. F.: Human complement system. In M. Samter: Immunological Diseases. p. 244-280 (Little Brown \& Co, Boston, 1978).

7. Krebs, R. A., and Burvant, M. V.: Nephrotic syndrome in association with varicella. J. Am. Med. Assoc., 222: 325 (1972)

8. Lachmann. P. J.: Complement. In P. G. H. Gell, R. R. A. Coombs, P. J.
Lachmann: Clinical Aspects of Immunology. p. 323-364 (Blackwell Scientific Publications, Oxford, 1975).

9. Lovejoy, F. H., Smith, A. L., Bresnan, M. J., Wood, J. N., Victor. D. I., and Adams, P. C.: Clinical staging in Reye syndrome. Am. J. Dis. Child., 128: 36 (1974).

10. Meyer sum Büschenfelde, Opferkuch, W., Vorgt, J., Forster, E., and Hopf. V.: Complement in acute and chronic liver disease. In: W. Opferkuch, K. Rother, D. R. Schultz: Clinical Aspects of the Complement System. p. 117-125 (Georg Thieme Publishers, Stuttgart, 1978)

11. Partin, J. C.: Reye's syndrome (encephalopathy and fatty liver): diagnosis and treatment. Gastroenterology, 69: 511 (1975).

12. Pickering, R. J., Urizar, R. E., Hanson, P. A., and Laffin, R. J.: Abnormalities of the complement system in Reye syndrome. J. Pediatr., 94: 218 (1979).

13. Schubert, W. K.: Commentary: the diagnosis of Reye syndrome. J. Pediatr., 87 867 (1975).

14. Smith, M. C. Cooke, J. H.. Zimmerman, D. M., Bird, J. J., Feaster, B. L. Morrison, R. E., and Reimann. B. E. F.: Asymptomatic glomerulonephritis after non-streptococcal upper respiratory infections. Ann. Intern. Med., 91:697 (1979)

15. Strife, C. F., McDonald, B. M., Ruley, E. J., McAdams, A. J., and West, C. D.: Shunt nephritis: the nature of serum cryoglobulins and their relation to the complement profile. J. Pediatr., 88: 403 (1976)

16. Thompson, R. A., Carter, R., Stokes, R. P., Geddes, A. M., and Goodall, J. A D.: Serum immunoglobulins, complement component levels, and autoantibodies in liver disease. Clin. Exp. Immunol., 14: 335, (1973).

17. Vallota. E. H., Forristal, J.. Spitzer, R. E., Davis, N. C., and West, C. D. Characteristics of a non-complement dependant $\mathrm{C} 3$ reactive complex formed from factors in nephritic and normal serum. J. Exp. Med., 151: 1306 (1970).

18. Van De Rign. I., Fillit, H., Brandeis, W. E., Reid, H., Poon-King, T., McCarthy, M., Day, N. K., and Zabriskie, J. B.: Serial studies on circulating immune complexes in post-streptococcal sequellae. Clin. Exp. Immunol., 34: 318 (1978)

19. Wyatt, R. J., Forristal, J., Davis, C. A., Coleman, T. H., and West, C. D.: Contro of serum C3 levels by $\beta 1 \mathrm{H}$ and C3bINA. J. Lab. Clin. Med., 95: 905 (1980).

20. Wyatt, R. J., McAdams, A. J., Forristal, J., Snyder, J., and West, C. D. Glomerular deposition of complement-control proteins in acute and chronic glomerulonephritis. Kidney Int.. 16: 505 (1979).

21. Requests for reprints should be addressed to: Harold K. Marder, M.D., Children's Hospital Research Foundation, 240 Bethesda Avenue, Cincinnati, OH 4522 (USA).

22. Supported in part by Institutional National Research Service Award AM 0705I from the National Institute of Arthritis, Metabolism and Digestive Disease (Dr. Marder), a Trustee Grant from the Children's Hospital Research Foundation (Dr. Strife). General Clinical Research Center Grant RR00123, and Biomedical General Research Support Grant RR05535-17.

23. Received for publication May 8. 1980.

24. Accepted for publication August 28, 1980 